Article

\title{
Genotype $\times$ Environment Interaction Patterns in Rangeland Variety Trials of Cool-Season Grasses in the Western United States
}

\author{
Joseph G. Robins * (D), Craig W. Rigby and Kevin B. Jensen \\ United States Department of Agriculture, Forage and Range Research Laboratory, Logan, UT 84322, USA; \\ craig.rigby@usda.gov (C.W.R.); kevin.jensen@usda.gov (K.B.J.) \\ * Correspondence: joseph.robins@usda.gov; Tel.: +1-435-797-2905
}

Received: 30 March 2020; Accepted: 24 April 2020; Published: 28 April 2020

check for updates

\begin{abstract}
Rangeland revegetation is necessary to stabilize disturbed sites and increase forage production, but frequently fails due to a variety of environmental and biotic factors. Plant breeding efforts in perennial cool-season grasses result in the development of potential cultivars that must be evaluated in multi-environment trials to determine their level of adaptation. This study evaluated 49 cultivars for stand frequency and dry matter yield over five years at five environments in the Intermountain and High Plains regions of the United States. The results were significant differences among the included cultivars for both traits across and within environments. Yet, there was also crossover genotype $\times$ environment interaction. Thus, highest performing cultivars were to some extent dependent on the environment. Hycrest II crested wheatgrass and Vavilov II Siberian wheatgrass possessed high stand frequency $(>80 \%)$ and dry matter yield $\left(>800 \mathrm{~kg} \cdot \mathrm{ha}^{-1}\right)$ across environments and within environments except at the Eureka, UT environment where they possessed low stand frequency. These cultivars, and species, also possessed high productivity and stability for both traits. Thus, breeding efforts in the species resulted in widely adapted cultivars that may lack specific adaptation to some environments.
\end{abstract}

Keywords: adaptation; dry matter yield; multi-environment trials; productivity; resilience; revegetation; stability; stand frequency

\section{Introduction}

Rangelands make up the earth's largest land surface type and provide livelihoods for millions of people that live on or near them [1]. Various disturbances, such as overgrazing, mining, weed invasion, and wildfire, result in the destabilization of much of the world's rangelands, including loss of topsoil to erosion, changes in soil structure and cycles, increased weed invasion, and increased wildfire frequency [2]. Much effort has been focused on the revegetation of these sites to stabilize the soil resources and to increase the forage production of the existing forage base [3]. Unfortunately, rangeland seeding for either revegetation after disturbance or to increase carrying capacity for livestock agriculture is fraught with difficulties due to the all too frequent failure of the seeded species to adequately establish [4].

To facilitate and make these revegetation efforts more effective, plant breeding programs were developed to focus on improvement of perennial cool-season grasses and forbs for rangeland settings. In the United States and Canada, several federal, state, and university perennial plant breeding programs developed regionally adapted species for the temperate regions of the Great Plains and Intermountain Regions [5]. Initially, these efforts focused primarily on improving common forage species, such as crested wheatgrass (Agropyron cristatum [L.] Gaertn. and Agropyron desertorum [Fisch. 
ex Link] Schult.) and smooth bromegrass (Bromus inermis Leyss.) [6]. More recently, efforts have increased to develop improved cultivars of native North American plant materials for conservation efforts rather than forage base improvement. The resulting cultivars proved effective in stabilizing soil on disturbed sites, combating annual weed invasion, and increasing forage bases for livestock and wildlife [6].

Like breeding programs for all crop species, there is a need to evaluate potential rangeland cultivars in multi-environment trials prior to cultivar release. However, unlike most row crops and alfalfa, variety trials of potential rangeland cultivars are generally ad hoc and uncoordinated across breeding programs. With few exceptions [7], individual rangeland breeding programs conduct their own variety trials at a handful of locations in their overall target environment [5]. Unfortunately, due to changes in priorities and directions at many of these institutions, the United States Department of Agriculture Forage and Range Research Laboratory (FRR) in Logan, UT is the last of the major rangeland cool-season grass breeding programs in the western United States. Because of this, the FRR is now tasked with developing cool-season grass cultivars for use across the entire region. This necessitates the development of cultivars with broad adaptation with a corresponding testing program that covers the possible growing locations [8]. The FRR breeding program develops improved perennial cool-season grass cultivars of over ten cool-season grass species for the extended Intermountain Region of the United States. Thus, to make proper recommendations and develop the best plant materials, the FRR breeding program must understand genotype $\times$ environment interaction that occurs both within and across species [9]. Genotype $\times$ environment interaction is the inconsistent performance of genotypes because of genotypic rank change or change in the magnitude of differences between genotypes without rank change [10]. Multi-location and -year evaluations determine not only the utility of potential cultivars, but also the extent of their area of adaptation [11]. This determination requires enough locations and years to sample the possible growing conditions in the target area of production [12]. Additionally, rangeland revegetation and agriculture occur on harsh sites that receive no inputs of irrigation, fertilization, or weed, insect, or disease control. Thus, it is critical to identify the species and cultivars that possess the greatest productivity, stability, and resilience across environments and years [13].

The purpose of this study was to characterize the genotype and genotype $\times$ environment effects associated with stand frequency and dry matter yield for newer cultivars developed by the FRR breeding program, standard older cultivars, and potential growing environments in the Intermountain and High Plains regions of the United States. Additionally, this study elucidated the productivity, stability, and resilience of these cultivars for these traits. This is critical to characterize the populations across the target region of the FRR breeding program, to determine the extent and cause of genotype $\times$ environment interaction associated with the plant materials, and to determine the most productive, stable, and resilient plant materials across environments.

\section{Materials and Methods}

Forty-nine perennial cool-season grass cultivars (15 species) were evaluated across five field environments between 2004 and 2014 (Table 1). The field sites and seeding years were Beaver, UT (2006), Cheyenne, WY (2009), Eureka, UT (2009), and Malta, ID (2004) (Table 2). Two trials were established at Cheyenne-one spring evaluated and harvested (Cheyenne Spring) and one fall evaluated and harvested (Cheyenne Fall) [14]. These five environments are representative of higher elevation (1500 to 2000 mas) rangeland environments in the Intermountain and High Plains regions of the USA and correspond to the Central Basins and Plains (Beaver and Eureka), Northern Basin and Range (Malta), and High Plains (Cheyenne) level III ecoregions [15]. Plant material native to each of these environments are perennial cool-season grasses and/or shrubs. The nine cultivars included in only a single trial were not included in the results, resulting in a dataset of 40 cultivars. Due to the inherently unbalanced nature of variety trials, not every cultivar was included at each environment. The number of cultivars 
included in each trial were 36 at Beaver, 21 at both Cheyenne trials, 34 at Eureka, and 26 at Malta. Ten cultivars were common to all five trials (Table 1).

The experimental design at each environment was a randomized complete block design with four complete blocks. Site preparation included mechanical cultivation the year prior to seeding, two applications of glyphosate ( $1518 \mathrm{~g}$ active ingredient $\mathrm{ha}^{-1}$ ) during the summer prior to seeding, and light cultivation followed by a harrower or cultipacker just prior to seeding. All environments were dormant seeded in November of the respective seeding year. Seeding was done with a six-row cone seeder equipped with press wheels and depth bands at a rate of one pure live seed $\mathrm{cm}^{-1}$ and at depth of 0.63 to $1.27 \mathrm{~cm}$. Plots were $1.5 \mathrm{~m} \times 6 \mathrm{~m}$ at Beaver, Eureka, and Malta; and $1.5 \mathrm{~m} \times 12 \mathrm{~m}$ at Cheyenne.

Table 1. List of perennial cool-season grass cultivars included in a series of five variety trials conducted at Beaver, UT, Cheyenne, WY, Eureka, UT, and Malta, ID from 2004 to 2014. An X in the trial name column indicates the inclusion of a cultivar in a specific trial (Cheyenne Spring and Fall trials consisted of the same cultivars) and the year is the year of cultivar release.

\begin{tabular}{|c|c|c|c|c|c|}
\hline Cultivar & Beaver & Cheyenne & Eureka & Malta & Year \\
\hline \multicolumn{6}{|c|}{$\begin{array}{c}\text { Basin wildrye } \\
\text { [Leymus cinereus (Scribn. \& Merr.) Á. Löve] }\end{array}$} \\
\hline Continental & $x$ & & $x$ & & 2009 [16] \\
\hline Magnar & $X$ & & $x$ & & 1979 [17] \\
\hline Trailhead & $x$ & $x$ & $x$ & & 1991 [18] \\
\hline Trailhead II & & $x$ & $X$ & & 2016 [19] \\
\hline \multicolumn{6}{|c|}{$\begin{array}{c}\text { Bluebunch wheatgrass } \\
\text { [Pseudoroegneria spicata (Pursh) Á. Löve] }\end{array}$} \\
\hline Anatone & $x$ & $x$ & $x$ & $x$ & $2003[20]$ \\
\hline Goldar & $x$ & & $x$ & $x$ & 1989 [21] \\
\hline P-7 & $x$ & $x$ & $X$ & $X$ & 2001 [22] \\
\hline \multicolumn{6}{|c|}{$\begin{array}{c}\text { Big squirreltail } \\
\text { [Elymus multisetus M.E. Jones] }\end{array}$} \\
\hline Sand Hollow & $x$ & & & $X$ & 1996 [23] \\
\hline \multicolumn{6}{|c|}{$\begin{array}{c}\text { Bottlebrush squirreltail } \\
\text { [Elymus elymoides (Raf.) Swezey] }\end{array}$} \\
\hline Fish Creek & $x$ & & $x$ & $x$ & $2003[24]$ \\
\hline Toe Jam Creek & $x$ & & $x$ & $x$ & 2003 [25] \\
\hline \multicolumn{6}{|c|}{$\begin{array}{l}\text { Crested wheatgrass } \\
\text { [Agropyron cristatum (L.) Gaertn. \& A. desertorum (Fisch. ex Link) Schult.] }\end{array}$} \\
\hline CD-II & $x$ & & $x$ & $x$ & $1996[26]$ \\
\hline Hycrest & $x$ & & $x$ & $X$ & 1984 [27] \\
\hline Hycrest II & $x$ & $x$ & $x$ & $x$ & 2008 [28] \\
\hline Nordan & $x$ & & $x$ & & 1953 [29] \\
\hline \multicolumn{6}{|c|}{$\begin{array}{c}\text { Indian ricegrass } \\
\text { [Achnatherum hymenoides (Roehmer \& J.A. Schultes) Barkworth] }\end{array}$} \\
\hline Nezpar & $x$ & & & $x$ & $1978[30]$ \\
\hline Rimrock & $x$ & & & $x$ & 1997 [31] \\
\hline White River & $x$ & & & $X$ & 2006 [32] \\
\hline \multicolumn{6}{|c|}{$\begin{array}{c}\text { Intermediate wheatgrass } \\
\text { [Thinopyrum intermedium (Host) Barkworth \& D.R. Dewey) }\end{array}$} \\
\hline Luna & & $x$ & $X$ & & 1963 [33] \\
\hline Oahe & $x$ & $x$ & $x$ & & 1961 [34] \\
\hline \multicolumn{6}{|c|}{$\begin{array}{c}\text { Meadow bromegrass } \\
\text { [Bromus biebersteinii Roem. \& Schult.] }\end{array}$} \\
\hline Arsenal & & $x$ & $x$ & & 2015 [35] \\
\hline Cache & & $x$ & $x$ & & 2004 [36] \\
\hline \multicolumn{6}{|c|}{$\begin{array}{c}\text { Russian wildrye } \\
\text { [Psathyrostachys junceus (Fisch.) Nevski] }\end{array}$} \\
\hline Bozoisky-Select & $x$ & & $x$ & $x$ & 1984 [37] \\
\hline Bozoisky II & $x$ & $x$ & $x$ & $x$ & $2006[38]$ \\
\hline \multicolumn{6}{|c|}{$\begin{array}{c}\text { Siberian wheatgrass } \\
\text { [Agropyron fragile (Roth) Candargy] }\end{array}$} \\
\hline Stabilizer & $x$ & & $x$ & $x$ & 2011 [39] \\
\hline Vavilov & $x$ & & $x$ & $x$ & 1994 [40] \\
\hline Vavilov II & $x$ & $x$ & $x$ & $x$ & 2008 [41] \\
\hline
\end{tabular}


Table 1. Cont.

\begin{tabular}{|c|c|c|c|c|c|}
\hline Cultivar & Beaver & Cheyenne & Eureka & Malta & Year \\
\hline \multicolumn{6}{|c|}{$\begin{array}{c}\text { Slender wheatgrass } \\
\text { [Elymus trachycaulus (Link) Gould ex Shinners] }\end{array}$} \\
\hline FirstStrike & $x$ & $x$ & $x$ & $x$ & 2006 [42] \\
\hline Pryor & $X$ & $x$ & $x$ & $X$ & 1988 [43] \\
\hline San Luis & $x$ & & $x$ & $x$ & 1984 [44] \\
\hline \multicolumn{6}{|c|}{$\begin{array}{l}\text { Smooth bromegrass } \\
\text { [Bromus inermis Leyss.] }\end{array}$} \\
\hline Manchar & $x$ & $x$ & $x$ & & 1943 [45] \\
\hline \multicolumn{6}{|c|}{$\begin{array}{c}\text { Snake River wheatgrass } \\
\text { [Elymus wawawaiensis J. Carlson \& Barkworth] }\end{array}$} \\
\hline Discovery & $x$ & $x$ & $x$ & & 2007 [46] \\
\hline Secar & $x$ & $x$ & $x$ & $X$ & 1981 [47] \\
\hline \multicolumn{6}{|c|}{$\begin{array}{l}\text { Thickspike wheatgrass } \\
\text { [Elymus lanceolatus (Scribn. \& J.G. Sm.) Gould] }\end{array}$} \\
\hline Bannock & $X$ & $x$ & $x$ & & $2003[48]$ \\
\hline Bannock II & $X$ & $x$ & $x$ & & 2015 [49] \\
\hline Critana & $x$ & $x$ & $x$ & & 1971 [50] \\
\hline \multicolumn{6}{|c|}{$\begin{array}{c}\text { Western wheatgrass } \\
\text { [Pascopyrum smithii (Rydb.) Á. Löve] }\end{array}$} \\
\hline Arriba & $x$ & & $x$ & $x$ & 1973 [51] \\
\hline Barton & $x$ & & & $x$ & 1970 [52] \\
\hline Recovery & $x$ & $x$ & $x$ & $x$ & 2009 [53] \\
\hline Rodan & $x$ & & & $x$ & 1983 [54] \\
\hline Rosana & $x$ & $x$ & $x$ & $x$ & 1972 [44] \\
\hline
\end{tabular}

Data collection began the spring after seeding at each environment and included stand frequency $(\%)$ and dry matter yield $\left(\mathrm{kg} \cdot \mathrm{ha}^{-1}\right)$. Stand frequency was evaluated using the method of Vogel and Masters [55], in which a grid was used to determine the percentage of ground containing live, rooted plant material in a $2.3 \mathrm{~m}$ long strip of the four inner rows in each plot. Dry matter was harvested once per year in mid- to late-June for all environments but Cheyenne Fall (October). Precipitation at each environment only allowed one mechanical harvest each year. Dry matter yield was collected using a sickle-bar forage harvester to remove above-ground forage to a stubble height of approximately $13 \mathrm{~cm}$. From each plot total wet forage weights were determined and then a representative forage sample was taken. The forage samples were placed in a forced air dryer at $60^{\circ} \mathrm{C}$ for five days. The sample dry weights were then used to adjust the total plot weights to a dry matter basis. Beginning in the spring of the establishment year, stand frequency was collected from each environment for five consecutive years. Dry matter yield was collected only from the Beaver and the two Cheyenne trials. At Beaver, dry matter yield was collected during years 3,4 , and 5 . At Cheyenne, dry matter yield was collected during years 2 and 4 for the spring trial and years 2,3, and 4 for the fall trial.

Table 2. Environment characteristics of the five environments included in the multi-year and -location evaluation of cool-season grasses on rangeland: Beaver, Utah; Cheyenne, Wyoming; Eureka, Utah; and Malta, Idaho.

\begin{tabular}{ccccc}
\hline Environment & Beaver & Cheyenne & Eureka & Malta \\
\hline Latitude & $38.3478 \mathrm{~N}$ & $41.1769 \mathrm{~N}$ & $39.9036 \mathrm{~N}$ & $42.3019 \mathrm{~N}$ \\
Longitude & $112.5892 \mathrm{~W}$ & $104.9011 \mathrm{~W}$ & $112.1497 \mathrm{~W}$ & $113.1950 \mathrm{~W}$ \\
Elevation (mas) & 1981 & 1901 & 1480 & 1789 \\
Soil & Silt loam & Silt loam & Silt loam & Silt loam \\
Mean Annual Precipitation $(\mathrm{mm})$ & 337 & 395 & 372 & 270 \\
Mean Annual Low Temperature $\left({ }^{\circ} \mathrm{C}\right)$ & 0.5 & 0.6 & -0.3 & 0 \\
Mean Annual High Temperature $\left({ }^{\circ} \mathrm{C}\right)$ & 16.4 & 14.6 & 16.6 & 15.8 \\
\hline
\end{tabular}

Data were analyzed according to mixed model methodology using the 'ASReml- $R$ ' package of the $R$ software package [56,57]. Specifically, environment, cultivar, and the cultivar $\times$ environment (genotype $\times$ environment) interaction were considered fixed effects. Year, block, and the interactions of year with the other main effects were considered random effects. The genotype $\times$ environment effect 
encompassed the differential effects of individual cultivars between environments, but across years. The repeated measures on the same plots across years were modeled using the rcov statement. The software produced estimates of best linear unbiased estimates with corresponding estimates of least significant difference (LSD) at the 5\% level for the fixed effects. Spearman rank correlation was estimated with the cor.test command in $\mathrm{R}$ to determine the relationship between stand frequency and dry matter yield across the environments from which both traits were collected.

Analyses of the genotype $\times$ environment interaction focused on the ten cultivars included in all five trials for stand frequency and the 17 cultivars included in all three trials for dry matter yield. GGE Biplots from the 'GGEBiplots' package of $\mathrm{R}$ were used to visualize the pattern of genotype $\times$ environment interaction based on the balanced dataset of best linear unbiased estimates for each cultivar in each environment with no missing data [58]. The GGEModel and the WhichWon commands were then used on the genotype and genotype $\times$ environment (tester) centered and unscaled data to create the resulting biplot figures for both traits (Figures 1 and 2).

Once the pattern of genotype $\times$ environment interaction was determined for stand frequency and dry matter yield, the productivity, stability, and resilience statistics were used to model cultivar performance across the environments using the complete dataset of the 40 cultivars [13]. These three statistics are based on the idea of a crisis year in which the performance for a trait of interest is significantly lower than all other years in an evaluation. The equations defined by Picasso et al. [13] are as follows:

Cultivar productivity $=$

$$
P_{j l}=\frac{\sum_{i}^{n-1} Y_{i j l}}{n-1}
$$

Cultivar stability $=$

$$
S_{j l}=\frac{P_{j l}}{\operatorname{SE}\left(P_{j l}\right)}
$$

Cultivar resilience $=$

$$
R_{j l}=\frac{Y c_{j l}}{P_{j l}}
$$

For a multi-year and -location trial with $i$ years, $j$ cultivars, and $l$ locations, $Y_{i j l}$ is the trait performance across $n-1$ non-crisis years of evaluation, $\operatorname{SE}\left(P_{j l}\right)$ is the standard error of the cultivar productivity, and $Y C_{j l}$ is the trait performance in the crisis year. Increased productivity, stability, and resilience correspond to greater trait performance, lower variability compared to the mean, and increased crisis year performance compared to the cultivar productivity, respectively.

Environment-cultivar specific values of productivity, stability, and resilience were then modeled with ASReml-R. The model considered both cultivars and environments to be fixed effects. The results were best linear unbiased estimates of cultivar productivity, stability, and resilience across environments.

\section{Results}

\subsection{Environments}

There were significant differences $(p=0.0009)$ among the stand frequency best linear unbiased estimates corresponding to each of the five environments (Table 3). Across years, Beaver and the two Cheyenne evaluations produced the greatest stand frequency (73\% to $86 \%$ ), while Eureka and Malta produced the lowest stand frequency ( $53 \%$ to $56 \%$ ). There were no differences $(p=0.12)$ among the best linear unbiased estimates from the three environments used for the dry matter yield evaluation (Table 3). There was a moderate rank correlation between stand frequency and dry matter yield across the Beaver and two Cheyenne environments $(\rho=0.56, p=0.001)$. 
Table 3. Across-year best linear unbiased estimates of stand frequency (SF; \%) evaluated over five years across and within five environments and dry matter yield (DMY, $\mathrm{kg} \mathrm{ha}^{-1}$ ) evaluated over three years across and within three environments. Estimates followed by the same lowercase, superscript letters in a column do not significantly differ based on the least significant difference (5\%).

\begin{tabular}{|c|c|c|c|c|c|c|c|c|c|c|}
\hline \multirow[t]{2}{*}{ Cultivar } & \multicolumn{2}{|c|}{ Overall } & \multicolumn{2}{|c|}{ Beaver } & \multicolumn{2}{|c|}{$\begin{array}{c}\text { Cheyenne } \\
\text { Spring }\end{array}$} & \multicolumn{2}{|c|}{ Cheyenne Fall } & \multirow{2}{*}{$\begin{array}{c}\text { Eureka } \\
\mathrm{SF}\end{array}$} & \multirow{2}{*}{$\begin{array}{r}\text { Malta } \\
\text { SF }\end{array}$} \\
\hline & SF & DMY & SF & DMY & SF & DMY & SF & DMY & & \\
\hline Anatone & $56^{\text {de }}$ & $458^{\mathrm{bc}}$ & $85^{b}$ & $683^{b-f}$ & $56^{d}$ & $307^{c-g}$ & $55^{\mathrm{e}}$ & $412^{b-d}$ & $33^{e}$ & $51^{\mathrm{d}}$ \\
\hline Bannock & & $553^{b c}$ & & $836^{b-d}$ & & $311^{\mathrm{c}-\mathrm{g}}$ & & $522^{b c}$ & & \\
\hline Bannock II & & $417^{b c}$ & & $623^{c-g}$ & & $214^{\mathrm{d}-\mathrm{g}}$ & & $411^{b-d}$ & & \\
\hline Bozoisky II & $78^{\mathrm{ab}}$ & $596^{\mathrm{b}}$ & $86^{\mathrm{b}}$ & $980^{\mathrm{b}}$ & $95^{\mathrm{a}}$ & $421^{\mathrm{c}-\mathrm{f}}$ & $93^{a}$ & $393^{b-d}$ & $55^{b-d}$ & $59^{\mathrm{cd}}$ \\
\hline Critana & & $316^{\mathrm{bc}}$ & & $496^{\mathrm{e}-\mathrm{h}}$ & & $157^{\mathrm{fg}}$ & & $305^{\mathrm{cd}}$ & & \\
\hline Discovery & & $515^{b c}$ & & $668^{\mathrm{c}-\mathrm{g}}$ & & $310^{c-g}$ & & $552^{\mathrm{bc}}$ & & \\
\hline FirstStrike & $68^{\mathrm{bc}}$ & $499 \mathrm{bc}$ & $83^{b}$ & $365 \mathrm{gh}$ & $76^{\mathrm{bc}}$ & $461^{\mathrm{cd}}$ & $79 \mathrm{abc}$ & $596^{\mathrm{b}}$ & $69^{\mathrm{ab}}$ & $35^{\mathrm{e}}$ \\
\hline Hycrest II & $79^{a}$ & $988^{a}$ & $91^{\mathrm{ab}}$ & $750^{b-e}$ & $86^{\mathrm{ab}}$ & $1087^{a}$ & $90^{\mathrm{ab}}$ & $1083^{a}$ & $45^{\text {de }}$ & $83^{a b}$ \\
\hline Manchar & & $574^{b c}$ & & $725^{b-f}$ & & $450^{\mathrm{c}-\mathrm{e}}$ & & $585^{\mathrm{b}}$ & & \\
\hline Oahe & & $991^{\mathrm{a}}$ & & $1320^{\mathrm{a}}$ & & $498^{c}$ & & $1081^{\mathrm{a}}$ & & \\
\hline $\mathrm{P}-7$ & $73^{a-c}$ & $552^{\mathrm{bc}}$ & $86^{b}$ & $695^{b-f}$ & $78^{\mathrm{a}-\mathrm{c}}$ & $378^{\mathrm{c}-\mathrm{g}}$ & $80^{a b c}$ & $616^{\mathrm{b}}$ & $67^{a-c}$ & $55^{\mathrm{cd}}$ \\
\hline Pryor & $53^{\mathrm{e}}$ & $530 \mathrm{bc}$ & $85^{\mathrm{b}}$ & $568^{\mathrm{d}-\mathrm{h}}$ & $58^{\mathrm{d}}$ & $339^{\mathrm{c}-\mathrm{g}}$ & $60^{\mathrm{e}}$ & $615^{\mathrm{b}}$ & $54^{\mathrm{cd}}$ & $9^{f}$ \\
\hline Recovery & $67^{c}$ & $528^{b c}$ & $88^{\mathrm{ab}}$ & $880^{b c}$ & $66^{\mathrm{cd}}$ & $184^{\mathrm{e}-\mathrm{g}}$ & 69 cde & $585^{\mathrm{b}}$ & $64^{\mathrm{a}-\mathrm{c}}$ & $51^{\mathrm{d}}$ \\
\hline Rosana & $68^{b c}$ & $309^{c}$ & $86^{\mathrm{b}}$ & $432^{\mathrm{f}-\mathrm{h}}$ & $71^{b-d}$ & $143^{g}$ & $76^{\mathrm{bcd}}$ & $409^{b-d}$ & $73^{a}$ & $34^{\mathrm{e}}$ \\
\hline Secar & $65^{\mathrm{cd}}$ & $518^{b c}$ & $74^{\mathrm{c}}$ & $728^{b-f}$ & $61^{\mathrm{cd}}$ & $283^{c-g}$ & $63^{\mathrm{de}}$ & $529 \mathrm{bc}$ & $58^{\mathrm{b}-\mathrm{d}}$ & $69^{b c}$ \\
\hline Trailhead & & $387^{b c}$ & & $806^{\mathrm{b}-\mathrm{d}}$ & & $131 \mathrm{~g}$ & & $231^{\mathrm{d}}$ & & \\
\hline Vavilov II & $81^{\mathrm{a}}$ & $831^{a}$ & $96^{a}$ & $633^{c-g}$ & $86^{\mathrm{ab}}$ & $806^{b}$ & $87^{\mathrm{ab}}$ & $1055^{\mathrm{a}}$ & $46^{\text {de }}$ & $86^{a}$ \\
\hline Environment & & & $86^{\mathrm{A}}$ & $724^{\mathrm{A}}$ & $75^{\mathrm{A}}$ & $377^{\text {B }}$ & $73^{A}$ & $586^{\mathrm{AB}}$ & $53^{C}$ & $56^{\mathrm{BC}}$ \\
\hline
\end{tabular}

Besides elevation, and among other things, the environments differed for latitude, longitude, soil, predominant species, temperature, and perhaps most importantly, annual precipitation [14]. Precipitation varied across environments and year-to-year within environments. Actual annual precipitation ranged from $175 \mathrm{~mm}$ (Malta, year 3) to $477 \mathrm{~mm}$ (Cheyenne, year 4) [14]. Mean annual precipitation at each environment ranged from $270 \mathrm{~mm}$ (Malta) to $395 \mathrm{~mm}$ (Cheyenne) and was $89 \%$ (Eureka) to $99 \%$ (Cheyenne) of the long-term (30 year) mean annual precipitation at each environment.

\subsection{Cultivars}

Analysis of the ten cultivars common to the five environments used for stand frequency and the 17 cultivars common to the three environments used for dry matter yield identified significant differences among the cultivars for both traits $\left(p=2 \times 10^{-6}\right.$ and $8 \times 10^{-8}$, for stand frequency and dry matter yield, respectively). Across environments, the greatest stand frequency $(\geq 73 \%)$ corresponded to Vavilov II Siberian wheatgrass, Hycrest II crested wheatgrass, Bozoisky II Russian wildrye, and P-7 bluebunch wheatgrass (Table 3$)$. While the greatest dry matter yield $\left(\geq 831 \mathrm{~kg} \cdot \mathrm{ha}^{-1}\right)$ corresponded to Oahe intermediate wheatgrass, Hycrest II crested wheatgrass, and Vavilov II Siberian wheatgrass (Table 3). Nevertheless, the analysis also identified genotype $\times$ environment interaction for stand frequency $\left(p=8 \times 10^{-16}\right)$ and dry matter yield $(p=0.002)$.

Examination of the genotype $\times$ environment interaction showed it to be the result of crossover interaction among the cultivars, rather than just simple change in magnitude differences among the cultivars (Table 3) [59]. For example, Hycrest II crested wheatgrass and Vavilov II Siberian wheatgrass were both in the statistically highest group of cultivars for stand frequency at four of the five evaluations. However, they were both in the lowest statistical group for stand frequency at the Eureka, UT evaluation. In contrast, Recovery western wheatgrass was among the cultivars with lower stand frequency at three evaluations but was among the cultivars with the highest stand frequency at Beaver and Eureka, UT. Spearman rank correlations among environments further supported the importance of crossover interaction in these evaluations. For both stand frequency and dry matter yield Spearman rank correlations were low and often did not significantly differ from zero $(\rho<0.50$, $n=10$ or 17). The exceptions were the correlations between the two Cheyenne evaluations, which were 
$\rho=1(p<0.0001, n=10)$ for stand frequency and $\rho=0.79(p<0.0001, n=17)$ for dry matter yield. The lack of concordance between rankings across environments further suggested the occurrence of rank changes among the cultivars at the different environments and supported the conclusion that the genotype $\times$ environment interaction was due to crossover interaction [60,61].

While illustrative and not statistical, the GGE biplot of stand frequency illustrated the patterns of genotype $\times$ environment interaction among environments and cultivars associated with this trait (Figure 1). The first two principal components accounted for $89 \%$ of the stand frequency variation and $95 \%$ of the dry matter yield variation. The Malta, and to a lesser extent Beaver, environments were characterized by the high stand frequency of Hycrest II crested wheatgrass and Vavilov II Siberian wheatgrass. The Cheyenne-Spring and Cheyenne-Fall environments were characterized by the high stand frequency of Bozoisky II Russian wildrye. The Eureka environment was characterized by the high stand frequency of FirstStrike slender wheatgrass and Rosana western wheatgrass. In contrast, Anatone bluebunch wheatgrass and Pryor slender wheatgrass possessed relatively poor stand frequency at most environments. The GGE biplot demonstrated the high dry matter yield of Oahe intermediate wheatgrass at the Beaver environment and the high dry matter yield of Hycrest II crested wheatgrass and Vavilov II Siberian wheatgrass at the two Cheyenne environments (Figure 2). The remaining cultivars possessed only moderate to low dry matter yield in each environment.

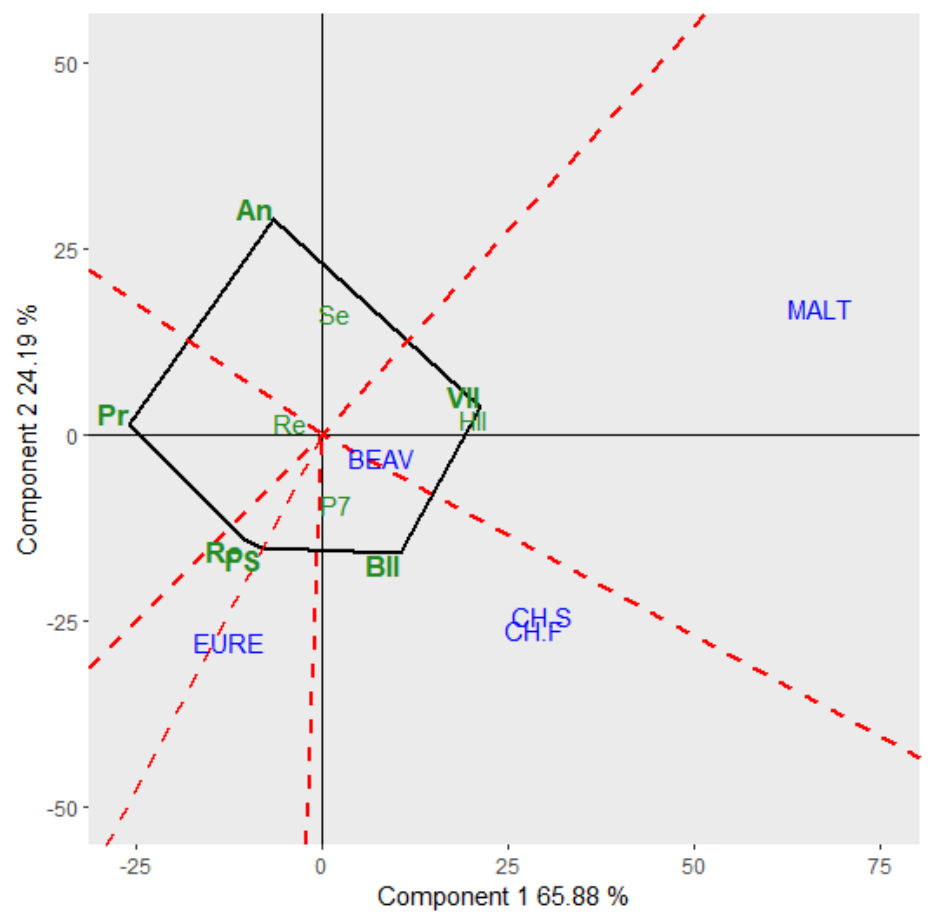

Figure 1. Which won where configuration of GGE Biplot figure of stand frequency (\%) evaluated on cool-season grass cultivars at rangeland environments in the Intermountain and High Plains regions of the USA. Environments are indicated in blue as follows: BEAV-Beaver, UT, CH.S-Cheyenne, WY-Spring, CH.F-Cheyenne, WY-Fall, EURE-Eureka, UT, and MALT-Malta, ID. Cultivars are indicated in green as follows: An-Anatone bluebunch wheatgrass, BoII-Bozoisky II Russian wildrye, FS-FirstStrike slender wheatgrass, HyII-Hycrest II crested wheatgrass, P7-P-7 bluebunch wheatgrass, Pr-Pryor slender wheatgrass, Re-Recovery western wheatgrass, Ro-Rosana western wheatgrass, Se-Secar Snake River wheatgrass, VaII—Vavilov II Siberian wheatgrass. 


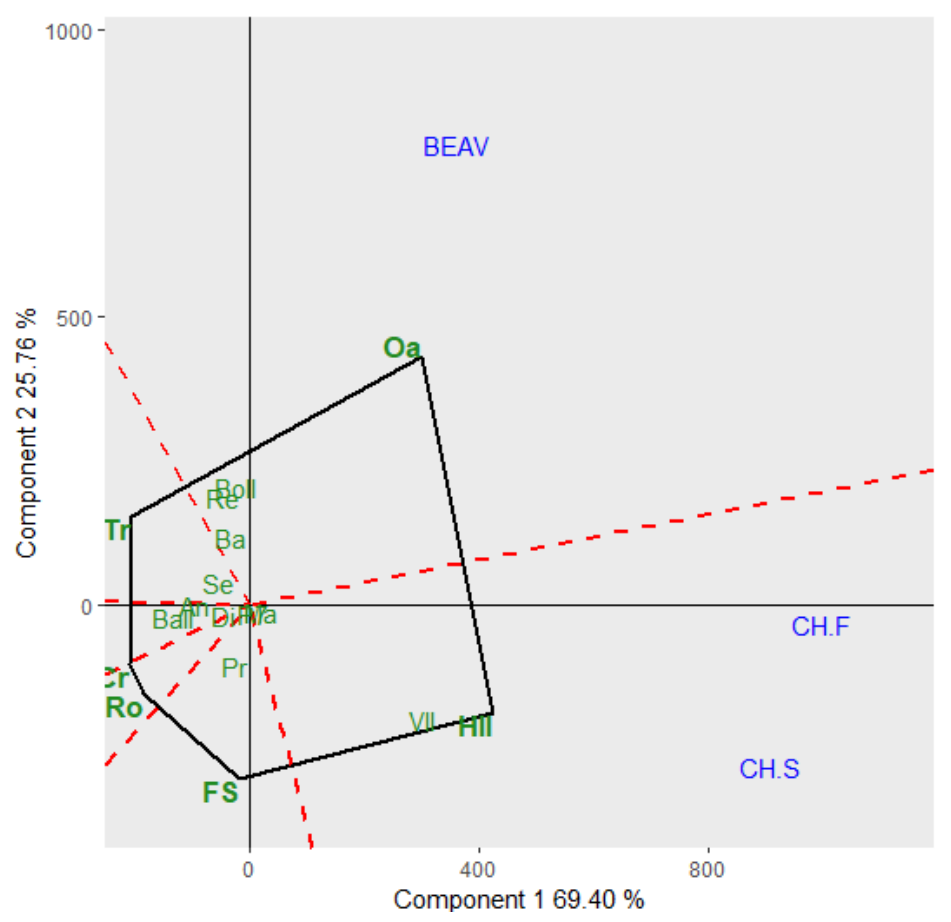

Figure 2. Which won where configuration of GGE Biplot figure of dry matter yield $\left(\mathrm{kg}^{\mathrm{h}} \mathrm{ha} \mathrm{C}^{-1}\right)$ evaluated on cool-season grass cultivars at rangeland environments in the Intermountain and High Plains regions of the USA. Environments are indicated in blue as follows: BEAV-Beaver, UT, CH.S-Cheyenne, WY-Spring, and CH.F-Cheyenne, WY-Fall. Cultivars are indicated in green as follows: An-Anatone bluebunch wheatgrass, Ba-Bannock thickspike wheatgrass, BaII-Bannock II thickspike wheatgrass, BoII-Bozoisky II Russian wildrye, Cr-Critana thickspike wheatgrass, Di-Discovery Snake River wheatgrass, FS—FirstStrike slender wheatgrass, HII-Hycrest II crested wheatgrass, Ma-Manchar smooth bromegrass, Oa-Oahe intermediate wheatgrass, P7—P-7 bluebunch wheatgrass, Pr-Pryor slender wheatgrass, Re-Recovery western wheatgrass, Ro-Rosana western wheatgrass, Se-Secar Snake River wheatgrass, Tr-Trailhead basin wildrye, VII-Vavilov II Siberian wheatgrass.

\subsection{Productivity, Stability, and Resilience}

Within each environment, stand frequency and dry matter yield differed from year to year (Table 4). These differences included the presence of a crisis year (a year with trait performance significantly lower than all other years) at each environment for stand frequency and dry matter yield [13]. For stand frequency, the crisis year occurred during establishment (year 1) for Beaver, both Cheyenne evaluations, and Eureka. At each of these environments, stand frequency started low, then increased at year 2, and then was similar, or decreased slightly (Eureka) over the course of the evaluation. In contrast, stand frequency started high at Malta and then decreased in the subsequent years, with the lowest stand frequency corresponding to year 5 . For dry matter yield, the crisis year was year 5 at Beaver, year 4 at Cheyenne-Spring, and year 3 for Cheyenne-Fall. At each environment, dry matter yield decreased from the first harvest year to the last harvest year. Crisis year severity ranged from 0.22 (Beaver) to 0.63 (Malta) for stand frequency and from 0.25 (Beaver) to 0.43 (Cheyenne-Fall) for dry matter yield.

The group of 18 cultivars with the highest stand frequency productivity possessed best linear unbiased estimates ranging from $72 \%$ to $91 \%$ for this trait (Table 5). This included one of the three bluebunch wheatgrasses, three of the four crested wheatgrasses, both intermediate wheatgrasses, both meadow bromegrasses, one of the two Russian wildryes, all three Siberian wheatgrasses, the smooth bromegrass, one of the two Snake River wheatgrasses, two of the three thickspike wheatgrasses, and two of the three western wheatgrasses. Hycrest II crested wheatgrass, Oahe intermediate wheatgrass, and Vavilov II Siberian wheatgrass possessed the greatest dry matter yield productivity $\left(\geq 1087 \mathrm{~kg} \cdot \mathrm{ha}^{-1}\right)$. In contrast, the lowest stand frequency productivity belonged 
to Nezpar indian ricegrass (30\%) and Magnar basin wildrye (41\%) and the lowest dry matter yield productivity corresponded to 13 cultivars $\left(\leq 730 \mathrm{~kg} \cdot \mathrm{ha}^{-1}\right)$.

Table 4. Annual best linear unbiased estimates of stand frequency (SF) and dry matter yield (DMY) evaluated on cool-season grasses over five years at five environments. Estimates followed by different lowercase, superscript letters in a column significantly differ based on the least significant difference.

\begin{tabular}{ccccccccc}
\hline & \multicolumn{2}{c}{ Beaver, UT } & \multicolumn{2}{c}{ Cheyenne, WY-S } & \multicolumn{2}{c}{ Cheyenne, WY-F } & Eureka, UT & \multicolumn{2}{c}{ Malta, ID } \\
\hline & SF & DMY & SF & DMY & SF & DMY & SF & SF \\
\hline Year & & & & & & & & \\
1 & $67^{\mathrm{d}}$ & - & $53^{\mathrm{d}}$ & - & $56^{\mathrm{b}}$ & - & $28^{\mathrm{e}}$ & $70^{\mathrm{a}}$ \\
2 & $82^{\mathrm{b}}$ & - & $84^{\mathrm{a}}$ & $679^{\mathrm{a}}$ & $84^{\mathrm{a}}$ & $779^{\mathrm{a}}$ & $66^{\mathrm{a}}$ & $57^{\mathrm{b}}$ \\
3 & $86^{\mathrm{a}}$ & $775^{\mathrm{a}}$ & $79^{\mathrm{b}}$ & - & $82^{\mathrm{a}}$ & $336^{\mathrm{c}}$ & $62^{\mathrm{b}}$ & $51^{\mathrm{c}}$ \\
4 & $85^{\mathrm{a}}$ & $639^{\mathrm{b}}$ & $73^{\mathrm{c}}$ & $257^{\mathrm{b}}$ & $80^{\mathrm{a}}$ & $449^{\mathrm{b}}$ & $59^{\mathrm{c}}$ & $42^{\mathrm{d}}$ \\
5 & $80^{\mathrm{c}}$ & $539^{\mathrm{c}}$ & $80^{\mathrm{ab}}$ & - & $80^{\mathrm{a}}$ & - & $55^{\mathrm{d}}$ & $21^{\mathrm{e}}$ \\
\hline
\end{tabular}

Table 5. Best linear unbiased estimates of productivity (P), stability (S), and resilience (R) for stand frequency (SF; \%) and dry matter yield (DMY, $\mathrm{kg}^{-h^{-1}}{ }^{-1}$ evaluated over multiple environments ( $\mathrm{N}=$ number of environments) and years. Estimates followed by different lowercase, superscript letters in a column significantly differ based on the least significant difference.

\begin{tabular}{|c|c|c|c|c|c|c|c|c|}
\hline Cultivar & $\mathbf{N}$ & SF_P & SF_S & SF_R & $\mathbf{N}$ & DMY_P & DMY_S & DMY_R \\
\hline Anatone & 5 & $63^{f-j}$ & $16.1^{e-j}$ & $0.6^{\mathrm{f}-\mathrm{h}}$ & 3 & $452^{\mathrm{e}-\mathrm{g}}$ & $4.2 \mathrm{ef}$ & $1.1^{\mathrm{a}}$ \\
\hline Arriba & 3 & $66^{c-j}$ & $16.0^{e-j}$ & $0.5^{\mathrm{gh}}$ & & & & \\
\hline Arsenal & 3 & $91^{\mathrm{a}}$ & $22.1^{\mathrm{ab}}$ & $1.1^{\mathrm{b}-\mathrm{e}}$ & 2 & $949^{a-d}$ & $8.2^{\mathrm{a}-\mathrm{d}}$ & $0.4^{\mathrm{bcd}}$ \\
\hline Bannock & 4 & $77^{a-g}$ & $19.3^{\mathrm{a}-\mathrm{f}}$ & $0.9^{c-g}$ & 3 & $571^{d-g}$ & $5.3^{c-f}$ & $0.8^{\mathrm{ab}}$ \\
\hline Bannock II & 4 & $66^{c-j}$ & $16.9^{\mathrm{c}-\mathrm{h}}$ & $0.9^{c-g}$ & 3 & $462^{\mathrm{e}-\mathrm{g}}$ & 4.2 ef & $0.6^{\mathrm{abcd}}$ \\
\hline Barton & 2 & $65^{d-j}$ & $16.1^{e-j}$ & $0.5 \mathrm{gh}$ & & & & \\
\hline Bozoisky-Select & 3 & $70^{\mathrm{b}-\mathrm{h}}$ & $17.7^{\mathrm{a}-\mathrm{g}}$ & $0.6^{\mathrm{f}-\mathrm{h}}$ & & & & \\
\hline Bozoisky II & 5 & $83^{\mathrm{a}-\mathrm{e}}$ & $20.5^{\mathrm{a}-\mathrm{e}}$ & $0.7^{\mathrm{e}-\mathrm{h}}$ & 3 & $647^{\mathrm{d}-\mathrm{g}}$ & $6.0^{\mathrm{c}-\mathrm{f}}$ & $0.7^{a b c}$ \\
\hline Cache & 3 & $84^{\mathrm{a}-\mathrm{d}}$ & $20.5^{\mathrm{a}-\mathrm{e}}$ & $1.0^{\mathrm{c}-\mathrm{f}}$ & 2 & $800^{c-f}$ & $7.0^{\mathrm{b}-\mathrm{e}}$ & $0.5^{\mathrm{bcd}}$ \\
\hline CD II & 3 & $79^{a-f}$ & $19.7^{\mathrm{a}-\mathrm{f}}$ & $0.6^{\mathrm{f}-\mathrm{h}}$ & & & & \\
\hline Continental & 2 & $66^{c-j}$ & $16.4^{\mathrm{d}-\mathrm{i}}$ & $0.8^{\mathrm{d}-\mathrm{h}}$ & & & & \\
\hline Critana & 4 & $72^{\mathrm{a}-\mathrm{g}}$ & $18.0^{a-g}$ & $0.6^{\mathrm{f}-\mathrm{h}}$ & 3 & $397^{f g}$ & $3.7^{\mathrm{ef}}$ & $0.5^{\mathrm{bcd}}$ \\
\hline Discovery & 4 & $72^{a-g}$ & $18.0^{\mathrm{a}-\mathrm{g}}$ & $0.7^{\mathrm{e}-\mathrm{h}}$ & 3 & $595^{\mathrm{d}-\mathrm{g}}$ & $5.6^{c-f}$ & $0.7^{a b c}$ \\
\hline FirstStrike & 5 & $68^{b-i}$ & $17.1^{\mathrm{c}-\mathrm{h}}$ & $1.3^{a-c}$ & 3 & $765^{c-f}$ & $6.7^{\mathrm{b}-\mathrm{e}}$ & $0.2^{\mathrm{d}}$ \\
\hline Fish Creek & 3 & $68^{b-i}$ & $17.3^{b-h}$ & $0.8^{\mathrm{d}-\mathrm{h}}$ & & & & \\
\hline Goldar & 3 & $65^{d-j}$ & $16.4^{\mathrm{d}-\mathrm{i}}$ & $1.2^{\mathrm{a}-\mathrm{d}}$ & & & & \\
\hline Hycrest & 3 & $85^{a-c}$ & $21.5^{a-c}$ & $0.7^{\mathrm{e}-\mathrm{h}}$ & & & & \\
\hline Hycrest II & 5 & $85^{a-c}$ & $21.3^{\mathrm{a}-\mathrm{d}}$ & $0.7^{\mathrm{e}-\mathrm{h}}$ & 3 & $1354^{\mathrm{a}}$ & $11.9^{\mathrm{a}}$ & $0.5^{\mathrm{bcd}}$ \\
\hline Luna & 3 & $82^{a-f}$ & $20.3^{\mathrm{a}-\mathrm{e}}$ & $1.0^{c-f}$ & 2 & $876^{\mathrm{b}-\mathrm{e}}$ & $8.7^{\mathrm{a}-\mathrm{c}}$ & $0.4^{\mathrm{bcd}}$ \\
\hline Magnar & 2 & $41^{\mathrm{k}-1}$ & $9.8^{\mathrm{kl}}$ & $0.6^{\mathrm{f}-\mathrm{h}}$ & & & & \\
\hline Manchar & 4 & $74^{\mathrm{a}-\mathrm{g}}$ & $18.4^{\mathrm{a}-\mathrm{f}}$ & $0.7^{\mathrm{e}-\mathrm{h}}$ & 3 & $730^{c-g}$ & $6.5^{b-f}$ & $0.5^{\mathrm{bcd}}$ \\
\hline Nezpar & 2 & $30^{1}$ & $6.0^{1}$ & $1.6^{\mathrm{a}}$ & & & & \\
\hline Nordan & 2 & $64^{e-j}$ & $15.8^{\mathrm{e}-\mathrm{j}}$ & $0.7^{\mathrm{e}-\mathrm{h}}$ & & & & \\
\hline Oahe & 4 & $84^{\mathrm{a}-\mathrm{d}}$ & $20.5^{\mathrm{a}-\mathrm{e}}$ & $1.0^{c-f}$ & 3 & $1264^{a b}$ & $11.9^{a}$ & $0.4^{b c d}$ \\
\hline $\mathrm{P}-7$ & 5 & $79^{a-f}$ & $19.7^{\mathrm{a}-\mathrm{f}}$ & $0.8^{\mathrm{d}-\mathrm{h}}$ & 3 & $616^{\mathrm{d}-\mathrm{g}}$ & $5.8^{\mathrm{c}-\mathrm{f}}$ & $0.7^{a b c}$ \\
\hline Pryor & 5 & $59^{g-k}$ & $14.9^{\mathrm{f}-\mathrm{j}}$ & $0.9^{c-g}$ & 3 & $750^{c-f}$ & $6.8^{\mathrm{b}-\mathrm{e}}$ & $0.3^{\mathrm{cd}}$ \\
\hline Recovery & 5 & $78^{a-g}$ & $19.6^{\mathrm{a}-\mathrm{f}}$ & $0.5^{\mathrm{gh}}$ & 3 & $507^{\mathrm{e}-\mathrm{g}}$ & $4.9^{\mathrm{d}-\mathrm{f}}$ & $0.8^{a b}$ \\
\hline Rimrock & 2 & $48^{\mathrm{j}-1}$ & $11.4^{\mathrm{jk}}$ & $1.5^{\mathrm{ab}}$ & & & & \\
\hline Rodan & 2 & $66^{c-j}$ & $16.1^{\mathrm{e}-\mathrm{j}}$ & $0.4^{\mathrm{h}}$ & & & & \\
\hline Rosana & 5 & $79^{\mathrm{a}-\mathrm{f}}$ & $19.5^{\mathrm{a}-\mathrm{f}}$ & $0.5^{\mathrm{gh}}$ & 3 & $295^{g}$ & $2.8^{f}$ & $1.0^{\mathrm{a}}$ \\
\hline San Luis & 3 & $49^{\mathrm{i}-1}$ & $11.8^{\mathrm{i}-\mathrm{k}}$ & $1.5^{\mathrm{ab}}$ & & & & \\
\hline Sand Hollow & 2 & $52^{\mathrm{h}-\mathrm{k}}$ & $12.6^{\mathrm{h}-\mathrm{k}}$ & $0.8^{\mathrm{d}-\mathrm{h}}$ & & & & \\
\hline Secar & 5 & $71^{\mathrm{b}-\mathrm{h}}$ & $17.9^{\mathrm{a}-\mathrm{g}}$ & $0.7^{\mathrm{e}-\mathrm{h}}$ & 3 & $628^{d-g}$ & $6.0^{c-f}$ & $0.7^{\mathrm{abc}}$ \\
\hline Stabilizer & 3 & $87^{a-b}$ & $22.3^{\mathrm{a}}$ & $0.6^{\mathrm{h}}$ & & & & \\
\hline Toe Jam Creek & 3 & $69^{\mathrm{b}-\mathrm{h}}$ & $17.5^{a-h}$ & $0.9^{c-g}$ & & & & \\
\hline Trailhead & 4 & $52^{\mathrm{h}-\mathrm{k}}$ & $13.4^{\mathrm{g}-\mathrm{k}}$ & $1.2^{\mathrm{a}-\mathrm{d}}$ & 3 & $488^{\mathrm{e}-\mathrm{g}}$ & $4.4^{\text {ef }}$ & $0.8^{\mathrm{ab}}$ \\
\hline Trailhead II & 3 & $66^{c-j}$ & $16.8^{c-h}$ & $1.2^{\mathrm{a}-\mathrm{d}}$ & 2 & $395 \mathrm{fg}$ & 3.5 ef & $0.7^{a b c}$ \\
\hline Vavilov & 3 & $81^{\mathrm{a}-\mathrm{f}}$ & $20.6^{\mathrm{a}-\mathrm{e}}$ & $0.7^{\mathrm{e}-\mathrm{h}}$ & & & & \\
\hline Vavilov II & 5 & $87^{a-b}$ & $21.7^{a-c}$ & $0.7^{\mathrm{e}-\mathrm{h}}$ & 3 & $1087^{a-c}$ & $9.9^{a b}$ & $0.5^{\mathrm{bcd}}$ \\
\hline White River & 2 & $63^{f-j}$ & $15.7^{e-j}$ & $1.1^{\mathrm{b}-\mathrm{e}}$ & & & & \\
\hline
\end{tabular}


The 21 cultivars with stand frequency stability best linear unbiased estimates greater than 17.4 comprised the group with the greatest stand frequency stability. This included the 18 cultivars with the greatest stand frequency productivity and Boizoisky-Select Russian wildrye, Secar Snake River wheatgrass, and Toe Jam Creek bottlebrush squirreltail. Hycrest II crested wheatgrass, Oahe intermediate wheatgrass, and Vavilov II Siberian wheatgrass possessed the greatest dry matter yield stability ( $\geq 9.9)$. The lowest stand frequency stability corresponded to Nezpar indian ricegrass (6.0) and Magnar basin wildrye (9.8). The same 13 cultivars with the lowest dry matter yield productivity also possessed the lowest dry matter yield stability $(\leq 6.5)$.

Nezpar indian ricegrass (1.6) and six other cultivars (1.2 to 1.5) possessed the greatest stand frequency resilience. Eleven cultivars, which did not include Hycrest II, Oahe, nor Vavilov II, possessed the greatest dry matter yield resilience $(>0.5)$. Twenty-four cultivars possessed the lowest stand frequency resilience ( 0.4 to 0.8$)$. Eleven cultivars were in the group with the lowest dry matter yield resilience $(\leq 0.5)$, including the three cultivars with the highest dry matter yield productivity and stability, Hycrest II crested wheatgrass, Oahe intermediate wheatgrass, and Vavilov II Siberian wheatgrass.

\section{Discussion}

The multi-environment trials focused on the core target production area of the FRR breeding program (the extended Intermountain United States) and because of the generally concurrent nature of the individual environmental trials, are reflective of the current status of the FRR breeding materials evaluated on potential production sites. As demonstrated by the declining stands in this multi-environment trial, extended rangeland data collection is problematic. Rangeland evaluations suffer from substantial plant mortality, which results in increasingly unbalanced datasets over time, both in cultivars and environments. These declining stands may be due to a harsher environment, such as Malta, and to a lesser extent Eureka in this multi-environment trial, or due to the biology of individual species that do not persist well over time. Additional years would provide a greater inference space for the genotype and genotype $\times$ environment results and provide more robust results for the productivity, stability, and resilience measures. However, we feel that this five-year dataset of stand frequency data and three-year dataset of dry matter yield data comprise a robust rangeland evaluation.

From these multi-environment trials, we identified clear differences among the included cultivars for stand frequency and dry matter yield across all environments and within each individual environment. We also found a moderate correlation between stand frequency and dry matter yield, which suggested that higher stand frequencies are associated with increased dry matter yield at these rangeland environments. Using the balanced data subset for the genotype $\times$ environment interaction, we found that the Siberian wheatgrass, crested wheatgrass, Russian wildrye, and bluebunch wheatgrass cultivars possessed the greatest stand frequency when evaluated across all five environments. We also found that the intermediate wheatgrass, crested wheatgrass, and Siberian wheatgrass cultivars possessed the greatest dry matter yield when evaluated across all three trials. We previously showed that these same "workhorse" species, although different cultivars, possessed high stand frequency across a broader section of environments in older trials [5]. Except for bluebunch wheatgrass, these are all native Eurasian species that are well-adapted to semiarid and arid rangeland agriculture and evolved under heavy domestic livestock grazing and in the presence of common annual weedy species, such as downy brome (Bromus tectorum L.) [62]. The native North American species evolved under no such pressure from grazing or annual weeds and, except for bluebunch wheatgrass stand frequency, proved to be less adapted to the disturbed sites used as environments in these trials [63]. Nonetheless, the overall results were not consistently indicative of the results at each individual environment as demonstrated by the crossover genotype $\times$ environment interaction $[59,64]$.

The genotype-environment interaction complicates the interpretation of trial results but is also the expectation when different genotypes are evaluated at a wide range of environments [65]. Further complicating the results of these trials are the inclusion of multiple species, rather than 
single species evaluated in most agronomic variety trials [66]. Due to the complexities of rangeland revegetation, including varying environmental factors and need for species diversification, the FRR rangeland plant breeding programs encompass several species for improvement. This results in a relatively small number of cultivars and improved populations for each species, which must be evaluated for adaptability and performance in multi-environment trials. The most efficient manner to do this is to combine them in the same trials. Thus, the point of these trials was not only to determine the improvement of new potential cultivars compared to previous cultivars of the same species, but also to determine which species have greater stand frequency and dry matter yield in a specific environment [5,7].

The GGE Biplots demonstrated the relationship among environments and cultivars and identified potential mega-environments and species-environment adaptations $[12,67]$. This visualization assists in the identification of mega-environments, or regions of a crop growing regions where similar genotypes perform best, by identifying the cultivar that performed best for a particular trait in each environment. The biplots derived from these evaluations suggested positive relationships among the Cheyenne, Beaver, and Malta environments for stand frequency. The high stand frequency of Hycrest II crested wheatgrass and Vavilov II Siberian wheatgrass at each of the four environments supported this conclusion. In contrast, the Eureka environment exhibited low to negative association with the other environments based on the stand frequency. This was illustrated by the low stand frequency of Hycrest II crested wheatgrass and Vavilov II Siberian wheatgrass at this environment. The dry matter yield suggested strong association between the two Cheyenne evaluations and little association between the Cheyenne evaluations and Beaver. Nevertheless, the dry matter yield biplot was less informative because of the limited number of environments and the high dry matter yield of Hycrest II crested wheatgrass in all three evaluations.

For the stand frequency data, there was evidence that Eureka formed a separate environment when compared to the other three environments. The reasons for this are not entirely clear. Previous research identified annual precipitation as the most important determinant of cool-season grass establishment and persistence on western USA rangeland [5]. Specifically, it showed that cool-season grass established and persisted poorly on sites receiving less than $\sim 300 \mathrm{~mm}$ of annual precipitation. This finding corresponded well to the Malta results. Malta received the least precipitation and had low stand frequency. However, Eureka also possessed low stand frequency, but received precipitation similar to or greater than the other environments. While highly correlated to stand frequency, precipitation is not the sole factor influencing stand frequency. Other factors affecting stand frequency include germination, crusting, and seed placement [68]. It appeared that the Beaver and Cheyenne environments constituted separate mega-environments for the dry matter yield data, although this should be considered inconclusive. The dataset included only the three environments and is not robust enough to make definitive conclusions. For both traits, the identification of definitive mega-environments will require more evaluations and specifically evaluations with more focus on individual species, i.e., many more genotypes representing each species.

Because the stand frequency crisis year at each environment but Malta was the establishment year, it showed that these species can increase stand frequency over time. This allows for greater establishment and stabilization of disturbed sites. Land managers value high levels of persistent stand frequency with desirable perennial plant species. more than high dry matter yield. High stand frequency stabilizes the soil resource, combats annual weeds and wildfires, and provides a dependable source of livestock and wildlife forage [3]. Approximately, half of the cultivars were among the group with the highest stand frequency productivity and stability. This list included representatives from almost every species and illustrated the success at the breeding program in developing cultivars of Eurasian and North American perennial cool-season grass species that provide good establishment and persistence on rangeland sites. The high dry matter yield productivity and stability of the Eurasian wheatgrass species illustrated that despite ongoing breeding these species possess the greatest dry matter yield potential and that the North American species may never approach comparably high 
levels of dry matter yield. High dry matter yield is an important trait on private rangelands for agriculture but is relatively unimportant on public rangelands where North American native species are more likely to be used and the emphasis is on revegetation and site stabilization [69].

Overall, this multi-environment trial illustrates the concept of selection for wide or specific adaptation put forward by Ceccarelli [8]. As other rangeland breeding programs ended, the FRR breeding program inherited a wider target production area. This necessitated an increased emphasis on developing cultivars that could be utilized across the entire target production region of the extended Intermountain United States. This is a practical reality that leads to widely adapted cultivars, but also leads to situations where the new cultivars are not well-adapted to specific environments, such as the poor stand frequency of Hycrest II crested wheatgrass and Vavilov II Siberian wheatgrass at the Eureka environment. Identification and selection within specific stress environments would result in greater rangeland revegetation success in a larger number of environments but is impossible with the resources available to most plant breeding programs. Yet, cooperation with individual land managers may make an approach like the participatory plant breeding strategy feasible for developing more specifically adapted rangeland cool-season grass cultivars [70]. Until that time, currently available cultivars from multiple species possess broad adaptation for use on Intermountain United States rangelands.

Author Contributions: Conceptualization, J.G.R, C.W.R., and K.B.J.; methodology, J.G.R.; formal analysis, J.G.R.; writing-original draft preparation, J.G.R.; writing—review and editing, C.W.R. and K.B.J.; All authors have read and agreed to the published version of the manuscript.

Funding: This research received no external funding.

Conflicts of Interest: The authors declare no conflict of interest.

\section{References}

1. Briske, D.D. Rangeland systems: Foundation for a conceptual framework. In Rangeland Systems: Processes, Management and Challenges; Briske, D.D., Ed.; Spring Open: Gewerbestrase, Switzerland, 2017; pp. 1-21.

2. Norton, J.B.; Monaco, T.A.; Norton, U. Mediterranean anual grasses in western North America: Kids in a candy store. Plant Soil 2007, 298, 1-5. [CrossRef]

3. Roundy, B.A. Lessons from historical rangeland revegetation for today's restoration. In Proceedings of the 1997 Society for Ecological Restoration Annual Meeting, Fort Lauderdale, FL, USA, 12-15 November 1997; pp. 33-38.

4. Knutson, K.C.; Pyke, D.A.; Wirth, T.A.; Arkle, R.S.; Pilliod, D.S.; Brooks, M.L.; Chambers, J.C.; Grace, J.B. Long-term effects of seeding after wildfire on vegetation in Great Basin shrubland ecosystems. J. Appl. Ecol. 2014, 51, 1414-1424. [CrossRef]

5. $\quad$ Robins, J.G.; Jensen, K.B.; Jones, T.A.; Waldron, B.L.; Peel, M.D.; Rigby, C.W.; Vogel, K.P.; Mitchell, R.B.; Palazzo, A.J.; Cary, T.J. Stand establishment and persistence of perennial cool-season grasses in the Intermountain West and the Central and Northern Great Plains. Rangel. Ecol. Manag. 2013, 66, 181-190. [CrossRef]

6. Asay, K.H.; Horton, W.H.; Jensen, K.B.; Palazzo, A.J. Merits of native and introduced Triticeae grasses on semiarid rangelands. Can. J. Plant Sci. 2001, 81, 45-52. [CrossRef]

7. Robins, J.G.; Waldron, B.L.; Vogel, K.P.; Berdahl, J.D.; Haferkamp, M.R.; Jensen, K.B.; Jones, T.A.; Mitchell, R.; Kindiger, B.K. Characterization of testing locations for developing cool-season grass species. Crop Sci. 2007, 47, 1004-1012. [CrossRef]

8. Ceccarelli, S. Wide adaptation: How wide? Euphytica 1989, 40, 197-205.

9. Cooper, M.; DeLacy, I.H. Relationships among analytical methods used to study genotypic variation and genotype-by-environment interaction in plant breeding multi-environment experiments. Theor. Appl. Genet. 1994, 88, 561-572. [CrossRef]

10. Crossa, J. From genotype $\times$ environment interaction to gene $\times$ environment interaction. Curr. Genom. 2012, 13, 225-244. [CrossRef]

11. Singh, M.; Ceccarelli, S.; Grando, S. Genotype $\times$ environment interaction of crossover type: Detecting its presence and estimating the crossover point. Theor. Appl. Genet. 1999, 99, 988-995. [CrossRef] 
12. Gauch, H.G., Jr.; Zobel, R.W. Identifying mega-environments and targeting genotypes. Crop Sci. 1997, 37, 311-326. [CrossRef]

13. Picasso, V.D.; Casler, M.D.; Undersander, D. Resilience, stability, and productivity of alfalfa cultivars in rainfed regions of North America. Crop Sci. 2019, 89, 800-810. [CrossRef]

14. Rigby, C.W.; Jensen, K.B.; Creech, J.E.; Thacker, E.T.; Waldron, B.L.; Derner, J.D. Establishment and trends in persistence of selected perennial cool-season grasses in western United States. Rangel. Ecol. Manag. 2018, 71, 681-690. [CrossRef]

15. United States Environmental Protection Agency: Ecoregions. Available online: Epa.gov/eco-research/ ecoregions (accessed on 25 February 2020).

16. Jones, T.A.; Parr, S.D.; Winslow, S.R.; Rosales, M.A. Notice of release of 'Continental' basin wildrye. Nativ. Plants J. 2009, 10, 57-61. [CrossRef]

17. Howard, C.G. 'Magnar' basin wildrye (Elymus cinereus Scribn \& Merr.) description adaption, use, culture, management and seed production. In Proceedings of the 19th Annual Meeting of the Nevada Committee on Conservation Plant Materials, Reno, NV, USA; 1979; pp. 28-31.

18. Cash, S.D.; Majerus, M.E.; Scheetz, J.C.; Holzworth, L.K.; Murphy, C.L.; Wichman, D.M.; Bowman, H.F.; Ditterline, R.L. Registration of 'Trailhead' basin wildrye. Crop Sci. 1998, 38, 278. [CrossRef]

19. Robins, J.G.; Bushman, B.S. Notice of release of 'Trailhead II' basin wildrye. Nativ. Plants J. 2016, 17, $273-280$. [CrossRef]

20. Monsen, S.B.; Memmott, K.; Shaw, N.; Pellant, M.; Young, S.; Ogle, D.; St. John, L. Notice to Release Anatone Germplasm Bluebunch Wheatgrass (Selected Class Natural poPulation); US Forest Service Rocky Mountain Research Station, Shrub Science Laboratory: Provo, UT, USA, 2003; p. 10.

21. Gibbs, J.L. Registration of 'Goldar' bluebunch wheatgrass. Crop Sci. 1991, 31, 1708. [CrossRef]

22. Jones, T.A.; Larson, S.R.; Nielson, D.C.; Young, S.A.; Chatterton, N.J.; Palazzo, A.J. Registration of P-7 bluebunch wheatgrass germplasm. Crop Sci. 2002, 42, 1754-1755. [CrossRef]

23. Jones, T.A.; Nielson, D.C.; Ogle, D.G.; Johnson, D.A.; Young, S.A. Registration of Sand Hollow squirreltail germplasm. Crop Sci. 1998, 38, 286. [CrossRef]

24. Jones, T.A.; Nielson, D.C.; Larson, S.R.; Jonson, D.A.; Monaco, T.A.; Caicco, S.L.; Ogle, D.G.; Young, S.A. Registration of Fish Creek bottlebrush squirreltail germplasm. Crop Sci. 2004, 44, 1879-1880. [CrossRef]

25. Jones, T.A.; Nielson, D.C.; Larson, S.R.; Jonson, D.A.; Monaco, T.A.; Caicco, S.L.; Ogle, D.G.; Young, S.A.; Carlson, J.R. Registration of Toe Jam Creek bottlebrush squirreltail germplasm. Crop Sci. 2004, 44, 1880-1881. [CrossRef]

26. Asay, K.H.; Chatterton, N.J.; Jensen, K.B.; Wang, R.R.C.; Johnson, D.A.; Horton, W.H.; Palazzo, A.J. Registration of 'CD-II' crested wheatgrass. Crop Sci. 1997, 37, 1023. [CrossRef]

27. Asay, K.H.; Dewey, D.R.; Gomm, F.B.; Johnson, D.A.; Carlson, J.R. Registration of 'Hycrest' crested wheatgrass. Crop Sci. 1985, 25, 368-369. [CrossRef]

28. Jensen, K.B.; Larson, S.R.; Waldron, B.L.; Robins, J.G. 'Hycrest II', a new crested wheatgrass cultivar with improved seedling establishment. J. Plant Reg. 2009, 3, 57-60. [CrossRef]

29. Hein, M.A. Registration of varieties and strains of wheatgrasses, II (Agropyron spp.), Nordan crested wheatgrass (Reg. No. 2). Agron. J. 1955, 47, 546. [CrossRef]

30. Booth, D.; Howard, C.; Mowry, C. 'Nezpar' indian ricegrass: Description, justification for release, and recommendations for use. Rangelands 1980, 2, 53-54.

31. Jones, T.A.; Majerus, M.E.; Scheetz, J.G.; Holzworth, L.K.; Nielson, D.C. Registration of 'Rimrock' Indian ricegrass. Crop Sci. 1998, 38, 539-540. [CrossRef]

32. Jones, T.A.; Winslow, S.R.; Parr, S.D.; Memmott, K.L. Notice of release of White River germplasm Indian ricegrass. Nativ. Plants J. 2010, 11, 133-136. [CrossRef]

33. Niner, G.C. Registration of Luna pubescent wheatgrass (Reg. No. 6). Crop Sci. 1967, 7, 683. [CrossRef]

34. Ross, J.G. Registration of Oahe intermediate wheatgrass (Reg. No. 5). Crop Sci. 1963, 3, 373. [CrossRef]

35. Jensen, K.B.; Singh, D.; Bushman, B.S.; Robins, J.G. Registration of 'Arsenal' meadow bromegrass. J. Plant Reg. 2015, 9, 304-310. [CrossRef]

36. Jensen, K.B.; Waldron, B.L.; Larson, S.R.; Peel, M.D. Registration of 'Cache' meadow bromegrass. Crop Sci. 2004, 44, 2263-2264. [CrossRef]

37. Asay, K.H.; Dewey, D.R.; Gomm, F.B.; Johnson, D.A.; Carlson, J.R. Registration of 'Bozoisky-Select' Russian wildrye. Crop Sci. 1985, 25, 575-576. [CrossRef] 
38. Jensen, K.B.; Asay, K.H.; Johnson, D.A.; Larson, S.R.; Waldron, B.L.; Palazzo, A.J. Registration of 'Bozoisky-II' Russian wildrye. Crop Sci. 2006, 46, 986-987. [CrossRef]

39. Jensen, K.B.; Bushman, B.S.; Waldron, B.L.; Robins, J.G.; Johnson, D.A.; Staub, J.E. 'Stabilizer', a new low-growing Siberian wheatgrass cultivar for use on semiarid lands. J. Plant Reg. 2012, 7, 89-94. [CrossRef]

40. Asay, K.H.; Johnson, D.A.; Jensen, K.B.; Chatterton, N.J.; Horton, W.H.; Hansen, W.T.; Young, S.A. Registration of 'Vavilov' Siberian crested wheatgrass. Crop Sci. 1995, 35, 1510. [CrossRef]

41. Jensen, K.B.; Palazzo, A.J.; Waldron, B.L.; Robins, J.G.; Bushman, B.S.; Johnson, D.A.; Ogle, D.G. 'Vavilov II', a new Siberian wheatgrass cultivar with improved persistence and establishment on rangelands. J. Plant Reg. 2009, 3, 61-64. [CrossRef]

42. Jensen, K.B.; Palazzo, A.J.; Waldron, B.L.; Bushman, B.S. Registration of 'FirstStrike' slender wheatgrass. Crop Sci. 2007, 1, 24-25. [CrossRef]

43. Majerus, M.E.; Scheetz, J.G.; Holzworth, L.K. Pryor Slender Wheatgrass, a Conservation Plant for Montana and Wyoming; USDA-SCS Agric. Leaflet Plant Materials Center: Bridger, MT, USA, 1991.

44. Alderson, J.; Sharp, W.C. Grass Varieties in the United States, Agriculture Handbook No. 170 ed; U.S. Department of Agriculture: Washington, DC, USA, 1994; p. 296.

45. Hein, M.A. Registration of varieties and strains of bromegrass (Bromus spp.) IV. Agron. J. 1960, 52, 406. [CrossRef]

46. Jones, T.A. Notice of release of 'Discovery' Snake River wheatgrass. Nativ. Plants J. 2008, 9, 99-101. [CrossRef]

47. Morrison, K.J.; Kelly, C.A. Secar Bluebunch Wheatgrass; Washington State University Thurston County Extension: Lacey, WA, USA, 1981.

48. USDA-NRCS; Idaho Agricultural Experiment Station. Notice of Release of 'Bannock' Thickspike Wheatgrass; Aberdeen Plant Materials Center: Aberdeen, ID, USA, 1995.

49. Robins, J.G.; Jensen, K.B.; Bushman, B.S. Notice of release of 'Bannock II' thickspike wheatgrass. Nativ. Plants J. 2015, 16, 259-264. [CrossRef]

50. Stroh, J.R.; Thornburg, A.A.; Ryerson, D.E. Registration of Critana thickspike wheatgrass. Crop Sci. 1972, 12, 394. [CrossRef]

51. Anonymous. Arriba Western Wheatgrass; New Mexico Coop: Los Lunas, NM, USA, 1977.

52. USDA Extension Service. New crop cultivars. Publ. ESC 1978, 13, $209-211$.

53. Waldron, B.L.; Jensen, K.B.; Palazzo, A.J.; Cary, T.J.; Robins, J.G.; Peel, M.D.; Ogle, D.G.; St. John, L. 'Recovery', a new western wheatgrass cultivar with improved seedling establishment on rangelands. J. Plant Reg. 2011, 5, 367-373. [CrossRef]

54. Barker, R.E.; Berdahl, J.D.; Jacobson, E.T. Registration of Rodan western wheatgrass. Crop Sci. 1984, 24, 1215-1216. [CrossRef]

55. Vogel, K.P.; Masters, R.A. Frequency grid: A simple tool for measuring grassland establishment. J. Range Manag. 2001, 54, 653-655. [CrossRef]

56. Butler, D.G.; Cullis, B.R.; Gilmour, A.R.; Gogel, B.J. ASReml-R Reference Manua, Version 3 ed; Queensland Department of Agriculture, Fisheries, and Forestry: Brisbane, Australia, 2009.

57. R Core Team. R: A Language and Environment for Statistical Computing; R Foundation for Statistical Computing: Vienna, Austria, 2018.

58. Dumble, S. GGEBiplots: GGE Biplots with 'Ggplot2'. R Package 0.1.1. Available online: https://cran.r-project. org/package=GGEBiplots (accessed on 30 March 2020).

59. De Leon, N.; Jannink, J.-L.; Edwards, J.W.; Kaeppler, S.M. Introduction to a special issue on genotype by environment interaction. Crop Sci. 2016, 56, 2081-2089. [CrossRef]

60. Vogel, K.P.; Reece, P.E.; Nichols, J.T. Genotype and genotype $\times$ environment interaction effects on forage yield and quality of intermediate wheatgrass in swards. Crop Sci. 1993, 33, 37-41. [CrossRef]

61. Conaghan, P.; Caseler, M.D.; McGilloway, D.A.; O'Kiely, P.; Dowley, L.J. Genotype × environment interactions for herbage yield or perennial ryegrass sward plots in Ireland. Grass Forage Sci. 2008, 63, 107-120. [CrossRef]

62. Young, J.A.; Clements, C.D. Cheatgrass: Fire and Forage on the Rangeland; University of Nevada Press: Reno, NV, USA, 2009; p. 348.

63. Jones, T.A.; Nielson, D.C.; Carlson, J.R. Developing a grazing-tolerant native grass for wheatgrass sites. Rangelands 1991, 13, 147-150.

64. Allard, R.W.; Bradshaw, A.D. Implications of genotype-environmental interactions in applied plant breeding. Crop Sci. 1964, 4, 503-508. [CrossRef] 
65. Ceccarelli, S. Specific adaptation and breeding for marginal conditions. In Breeding Fodder Crops for Marginal Conditions; Rognli, O.A., Solberg, E., Schjelderup, I., Eds.; Springer: Dordrecht, The Netherlands, 1994; pp. 101-127.

66. Laidig, F.; Drobek, T.; Meyer, U. Genotypic and environmental variability of yield for cultivars from 30 different crops in German official variety trials. Plant Breed. 2008, 127, 541-547. [CrossRef]

67. Yan, W.; Hunt, L.A.; Sheng, Q.; Szlavnics, Z. Cultivar evaluation and mega-environment investigation based on GGE Biplot. Crop Sci. 2000, 40,597-605. [CrossRef]

68. Madsen, M.D.; Davies, K.W.; Williams, C.J.; Svejcar, T.J. Agglomerating seeds to enhance native seedling emergence and growth. J. Appl. Ecol. 2012, 49, 431-438. [CrossRef]

69. Robins, J.G.; Waldron, B.L.; Jensen, K.B. Productivity, stability, and resilience of cool-season perennial grasses used for rangeland revegetation. Agrosys. Geosci. Environ. 2020. [CrossRef]

70. Ceccarelli, S. Efficiency of plant breeding. Crop Sci. 2015, 55, 87-97. [CrossRef]

(C) 2020 by the authors. Licensee MDPI, Basel, Switzerland. This article is an open access article distributed under the terms and conditions of the Creative Commons Attribution (CC BY) license (http://creativecommons.org/licenses/by/4.0/). 